\title{
El terrorismo en la Constitución chilena
}

\author{
Myrna Villegas Díaz*
}

\begin{abstract}
RESUMEN
El presente artículo analiza críticamente el tratamiento del terrorismo en la Constitución de 1980, tomando posición acerca del pronunciamiento respecto de la materia en la Carta Fundamental. Plantea que en el contexto nacional del cambio constitucional no es necesario un pronunciamiento en la materia, pues el reconocimiento constitucional del terrorismo conduciría a la consagración de un mecanismo de protección represivo de la democracia que atenta contra su legitimidad. Para fundamentar su postura, la autora revisa la regulación constitucional comparada del terrorismo, así como su consagración en Chile y las implicancias que ha tenido esta en términos normativos y en la jurisprudencia, principalmente en lo referido a la afectación de derechos fundamentales.
\end{abstract}

Terrorismo - Constitución - democracia

\section{Terrorism in the chilean Constitution}

\begin{abstract}
This paper critically analyzes the current constitutional treatment of terrorism in the 1980 Constitution, taking position on the need for a ruling on the matter in the Constitution. He argues that in the national context on constitutional change is not necessary a ruling on the matter, as the constitutional recognition of terrorism lead to the consecration of a repressive mechanism protection of democracy that undermines its legitimacy. In support of its position, the author reviews the comparative constitutional regulation of terrorism and its consecration in Chile and the implications that has had it in normative terms and jurisprudence, particularly with regard to the impact on fundamental rights.
\end{abstract}

Terrorism - constitution - democracy

* Doctora en derecho y postgraduada en criminología, Universidad de Salamanca. España. Investigadora del Centro de Derechos Humanos de la Facultad de Derecho, Universidad de Chile. Correo electrónico: mvillegas@derecho.uchile.cl.

Este trabajo se realiza en el marco del proyecto Fondecyt Regular $\mathrm{N}^{\circ} 1140040$, "Terrorismo y democracia. Bases para un concepto jurídico de terrorismo en el derecho penal chileno y examen de núcleos problemáticos en su actual regulación", del que su autora es investigadora responsable. Se agradecen las observaciones al borrador por parte del seminario de investigación integrado por los profesores JP. Mañalich, C. Cárdenas y J. Winter, y los ayudantes JC. Sharp, F. Bonzi, N. Navarrete y C.Núñez.

Artículo recibido el 29 de enero de 2016 y aceptado para su publicación el 30 de agosto de 2016. 


\section{INTRODUCCIÓN}

$\mathrm{C}$ hile parece haber tomado el camino hacia un cambio constitucional que supone la revisión o abandono de viejas concepciones heredadas de la dictadura militar, entre estas se encuentra el sui generis pronunciamiento que ella hace acerca del terrorismo. En esta tarea y a la luz de la expansión de la normativa antiterrorista a nivel mundial, conviene hacer un examen de la normativa antiterrorista constitucional vigente, con el objeto de evitar que la nueva carta fundamental pueda verse trastocada por los criterios de la emergencia que prevalecen en el ámbito europeo y norteamericano a consecuencia del terrorismo islámico.

La interrogante que aquí se plantea es si a la luz de la creciente demanda por seguridad debe la Constitución pronunciarse respecto del terrorismo. La hipótesis desde la que se parte es que un pronunciamiento constitucional en la materia solo podría conducir a un medio de protección represivo de la democracia, manifestado en severas restricciones a garantías individuales, lo que podría garantizar su permanencia y estabilidad, pero a costa de su legitimidad. Ello porque cualquier pronunciamiento constitucional del terrorismo inevitablemente implica un vaciamiento de derechos y libertades con lo que se contraría a la propia Constitución ${ }^{1}$. Con el fin de someter esta hipótesis a verificación, el ejercicio que realizaremos será el siguiente: describiremos someramente lo que sucede en la legislación comparada, luego examinaremos la regulación constitucional del terrorismo en nuestro país a la luz de los principios generales del derecho penal y de los derechos humanos internacionalmente reconocidos, para finalmente y a la luz de lo expuesto, argumentar en favor de la exclusión de normas concernientes al terrorismo en una futura Constitución.

\section{REGULACIÓN CONSTITUCIONAL DEL TERRORISMO EN LA LEGISLACIÓN COMPARADA}

En la legislación comparada no hay un modelo único de regulación constitucional, pues solo algunas constituciones se pronuncian sobre el terrorismo ${ }^{2}$, observándose principalmente en algunos países europeos, p. ej., Alemania y España. Sin embargo, este pronunciamiento no implica el establecimiento de restricciones específicas a garantías individuales, más bien se trata de normas que hacen referencia genérica a suspensiones

${ }^{1}$ Similar planteamiento, pero con matices que se verán más adelante, Carrasco, M., “Medidas antiterroristas y Constitución tras el 11 de septiembre de 2001”, en Pérez Royo, J. (dir.) y Carrasco, M. (coord.), Terrorismo, democracia y seguridad, en perspectiva constitucional, Editorial Marcial Pons, Madrid, 2010, pp. 15 y 17 y Ruiz-Tagle, P. “Constitucionalismo y terrorismo”, en SELA (Seminario en Latinoamérica de Teoría Constitucional y Política), Paper $\mathrm{N}^{\circ}$ 12, 2002, disponible en: http://digitalcommons.law.yale.edu/yls_sela/12 (consulta: 20-01-2016), p. 5.

${ }^{2}$ Aguirre, F. y Bustos, R. “Terrorismo y Constitución de 1980, con especial referencia a la aplicación de la ley antiterrorista en el marco del conflicto del Estado con el pueblo mapuche”, en Anuario de Derecho Público, Universidad Diego Portales, 2014, pp.173-201, p. 180. 
de derechos, o bien a casos en los que se ve comprometida la defensa nacional. En el primer caso, la Constitución española enuncia expresamente a la suspensión de algunos derechos fundamentales para casos de terrorismo (art. 55.2). En el segundo caso la Ley Fundamental en Alemania establece competencia legislativa a la Federación para regular los mecanismos de defensa frente a los peligros del terrorismo internacional (art. 73.9), pero no establece explícitamente la posibilidad de suspender garantías.

Paradigmático es que en aquellos países en los que presuntamente hay o hubo más brotes de violencia llamada terrorista (no necesariamente islámica), no existen referencias expresas al mismo en sus constituciones. Así sucede p. ej. con EE.UU., en donde ni siquiera se lo mencionó en las enmiendas constitucionales posteriores a 2001; con Reino Unido, que no se refiere a él en sus normas fundamentales. En el caso francés, la Constitución de 1958 se refiere a una generalidad de casos en los que podrían suspenderse derechos y libertades públicas en resguardo de la defensa nacional (art. 34), pero no menciona explícitamente al terrorismo, ni siquiera internacional. Esta tendencia cambia tras los atentados de Paris en 2015, pues se ha presentado un proyecto de ley para constitucionalizar el estado de emergencia y privar de la nacionalidad francesa a quienes tienen doble nacionalidad y son condenados por delitos de terrorismo ${ }^{3}$.

En América Latina, pocos son los países que contienen normas constitucionales acerca del mismo. Al igual que en el caso anterior, llama la atención que este pronunciamiento no exista en los mal llamados países del narcoterrorismo como México y Colombia, y sí exista en otros en los que el nivel de violencia es inferior comparado con aquellos, como sucede con Brasil, Perú y Chile. En estos últimos se adopta un modelo sobrecargado que constitucionaliza ciertas restricciones de derechos fundamentales que ordinariamente están en la legislación penal y procesal.

La Constitución brasileña de 1988 hace referencia al terrorismo tanto en sus principios fundamentales como en relación con garantías penales. Normativiza en su título I, como principio orientador y fundamental de las relaciones internacionales, el repudio al terrorismo y racismo (art.4) y establece un patrón general de un régimen punitivo más severo en casos de terrorismo ${ }^{4}$, que se manifiesta no solo en el establecimiento de restricciones a derechos y garantías, sino asimismo en la alteración, vía constitución, de reglas ordinarias de participación. Así, por un lado, priva a los delitos de terrorismo de la posibilidad de fianza, indulto o amnistía (art. $5 \mathrm{~N}^{\circ} 42$ primera parte), y por otro lado, altera las normas generales al establecer la responsabilidad penal por estos delitos no solo a los incitadores y los ejecutores (que eso todavía está dentro de la norma general),

${ }^{3}$ Conseil d'État Assemblée Générale. Section de l'intérieur. No 390866. Extrait du registre des deliberations Séance du vendredi 11 décembre 2015. Avis sur le projet de loi constitutionnelle de protection de la Nation. NOR: PRMX1529429L, disponible en: http://www.gouvernement.fr/sites/default/files/contenu/ piece-jointe/2015/12/avis_du_conseil_detat_sur_le_projet_de_loi_constitutionnelle_de_protection_de_la_nation. pdf (consulta: 20-01-2016).

${ }^{4}$ Zilli, M.; Monteconrado, F. y Moura, M.T., “Terrorismo e o direitto brasileiro”, en Ambos, K.; Malarino, E. y Steiner, C. (eds.), Terrorismo y derecho penal, Konrad Adenauer Stiftung, Edpal, Bogotá, 2015, pp. 521-553, pp. 524-525. 
sino asimismo a "los que pudiendo evitarlos se abstuvieran" (art. 5.42 segunda parte). Esto es, un castigo expreso para el "no desistimiento". Además, dispone como delitos no afianzables e imprescriptibles a las acciones de grupos armados civiles o militares, contra el orden institucional y el Estado democrático, es decir, conductas propias del terrorismo o relacionadas con él ${ }^{5}$.

La Constitución peruana de 1993 establece en forma expresa la suspensión de garantías. Así, restringe el derecho a la libertad y seguridad individual concediendo un plazo de detención para casos de terrorismo de quince días, superior a las 24 horas en otros casos (art. 2.24), permite aplicar la pena de muerte (art. 140), y concede fuero militar para el juzgamiento de casos de terrorismo. Además, y en sintonía con la tendencia europea iniciada con la cláusula belga o del atentado ${ }^{6}$, priva al terrorista del privilegio extraditorio (art. 137).

La Constitución chilena de 1980 hace referencia al terrorismo en sus tres primeros capítulos, por un lado, en las bases de la institucionalidad (Cap.1), que entrega orientaciones para un concepto de terrorismo y establece sanciones accesorias; luego en las normas sobre nacionalidad y ciudadanía (Cap.2), que regula la suspensión de derechos políticos para casos de terrorismo; y por último, entre los derechos y deberes fundamentales, para restringir el derecho a la libertad ambulatoria (cap.3). Examinaremos estas disposiciones.

\section{EL TERRORISMO EN LAS BASES DE LA INSTITUCIONALIDAD CHILENA Y EN LOS MECANISMOS DE PARTICIPACIÓN DEMOCRÁTICA}

\section{Un poco de historia: la apología del terrorismo}

Las bases de la institucionalidad reflejan el espíritu del constituyente a la época de su dictación. En su versión original, la primera norma que hacía referencia al terrorismo era el artículo $8^{\circ}$ que regulaba la apología del terrorismo y demonizaba a cierto tipo de infractores ${ }^{7}$. En su virtud fue requerido de inconstitucionalidad don Clodomiro Almeyda Medina, ex-Presidente del Partido Socialista de Chile. La Sentencia del Tribunal

\section{${ }^{5}$ Ibid, p. 525.}

${ }^{6}$ Establecida mediante la Ley Belga de Extradición de 1856.

7 Artículo $8^{\circ}$.- Todo acto de persona o grupo destinado a propagar doctrinas que atenten contra la familia, propugnen la violencia o una concepción de la sociedad, del Estado o del orden jurídico, de carácter totalitario o fundada en la lucha de clases, es ilícito y contrario al ordenamiento institucional de la República.

Las organizaciones y los movimientos o partidos políticos que por sus fines o actividad de sus adberentes tiendan a esos objetivos, son inconstitucionales.

Sin perjuicio de las demás sanciones establecidas en la Constitución o en la ley, las personas que incurran o hayan incurrido en las contravenciones señaladas precedentes no podrán optar a funciones o cargos públicos, sean o no de elección popular, por el término de diez años.

Tampoco podrán ser rectores o directores de establecimientos de educación ni ejercer en ellos funciones de enseñanza, ni explotar un medio de comunicación social o ser directores o administradores del mismo, ni desempeñar en él funciones relacionadas con la emisión o difusión de opiniones o informaciones; ni podrán ser dirigentes de organizaciones políticas o 
Constitucional Rol No 46 de 21 de diciembre de 1987, da cuenta del requerimiento formulado por el Ministerio del Interior, en el que se hacía una aplicación directa de la norma constitucional a una persona solicitando se declare la responsabilidad de José Clodomiro Almeyda Medina por "haber incurrido en actos que propagan doctrinas que propugnan la violencia como también en actos que propagan doctrinas que propugnan una concepción de la sociedad, del Estado o del orden jurídico de carácter totalitario, e igualmente en actos destinados a propagar doctrinas fundadas en la lucha de clases" aplicándosele las sanciones constitucionales y legales correspondientes.

Los documentos a cuyo través se habría realizado la apología al terrorismo y que motivaron el requerimiento eran, entre otros, una convocatoria hecha por el requerido al XXIV Congreso General Ordinario del Partido Socialista de Chile ${ }^{8}$, una noticia del diario El Mercurio9, y entrevistas en las revistas APSI y Qué Pasa.

El requerido alegó, entre otros, la incompatibilidad del art. $8^{\circ}$ con la libertad de pensamiento y el derecho a participar en la vida ciudadana de su país consagrados en los arts. 18 y 21 de la Declaración Universal de Derechos Humanos y en los arts. 18 y 25 del Pacto Internacional de Derechos Civiles y Políticos. El Tribunal Constitucional afirmó explícitamente la prevalencia del orden jurídico interno por sobre las normas de tratados internacionales, declarando además que la finalidad del artículo $8^{\circ}$ era proteger la democracia y preservar los valores básicos en que se funda la institucionalidad, por lo que este no vulnera normas internacionales, ya que estas no deben interpretarse en el sentido de conferir derechos a personas o grupos de personas para realizar actos tendientes a destruir los valores aludidos ${ }^{10}$.

El requerido alegó también una contradicción entre el art. $8^{\circ}$ y el art. 5 inciso 2 de la propia Constitución. El Tribunal Constitucional declaró que ella era inexistente, toda vez que los valores proclamados en las bases de la institucionalidad eran inamovibles, y que todo acto que propenda a la destrucción de estos principios, en el hecho atenta contra la dignidad del ser o contra los derechos que emanan de la naturaleza bumana, contra la familia

relacionadas con la educación o de carácter vecinal, profesional, empresarial, sindical, estudiantil o gremial en general, durante dicho plazo.

Las personas referidas anteriormente que estuvieren a la fecha de declaración del tribunal en posesión de un empleo o cargo público, sea o no de elección popular, lo perderán, además, de pleno derecho.

Las personas sancionadas en virtud de este precepto no podrán ser objeto de rehabilitación durante el plazo señalado en el inciso cuarto.

La duración de las inhabilidades contempladas en este artículo se elevará al doble en caso de reincidencia.

${ }^{8}$ Entre los párrafos de dicha convocatoria destaca el Tribunal Constitucional el siguiente: No puede cuestionarse el derecho de la resistencia a la opresión y a la rebeldía, cuando los regímenes opresores desnudan su carácter de dictadura represiva de clase, ni el derecho al uso de todas las formas de lucha, incluso la violencia revolucionaria, cuando no hay otro camino para recuperar su soberanía y trabajar por el imperio de la justicia y darle vigencia real a la libertad.

${ }^{9}$ Noticia de El Mercurio, de 28 de agosto de 1985 que publicaba un cable proveniente de Buenos Aires con el título de Almeyda propicia la lucha armada, en el que afirma todas las formas de lucha que se dé el pueblo para derrocar a la dictadura de Augusto Pinochet, son legítimas.

${ }^{10}$ Tribunal Constitucional. Sentencia de 22-06-1987, rol No 46-87, párrafos 27 y 29 de consideraciones de fondo. 
o contra el orden jurídico democrático ${ }^{11}$. Y en su concepto, el marxismo destruía tales valores $^{12}$. Así, acogió el requerimiento, aunque con tres votos disidentes ${ }^{13}$, y declaró que el requerido era responsable de haber infringido el inciso primero del artículo $8^{\circ}$ de la Constitución. Esta norma fue derogada posteriormente por la Ley de Reforma Constitucional $\mathrm{N}^{0} 18.825$ de 17 agosto de 1989. Sin embargo subsiste el art. 9 que tiene su mismo fundamento ideológico.

\section{La normativa subsistente en las bases de la institucionalidad y los derechos ciudadanos}

El art. 9 de la Constitución ${ }^{14}$ contiene cuatro importantes consideraciones:

a) Esboza un concepto al declarar que el terrorismo "es esencialmente contrario a los derechos humanos".

b) Ordena al legislador regular las conductas terroristas mediante una ley de quórum calificado.

c) Establece penas accesorias de inhabilitación especial para el condenado por delitos de terrorismo, por un plazo de 15 años. Tales inhabilitaciones son impedimentos para el ejercicio de cargos o funciones públicas, sean o no de elección popular, ser rector o director de un establecimiento de educación, o para ejercer en ellos labores de enseñanza, explotar un medio de comunicación social o ser director, administrador o desempeñar funciones de difusión de información. También para ser dirigente de organizaciones políticas, educacionales, vecinales, gremiales, estudiantiles, profesionales, empresariales o sindicales.

d) Considera explícitamente al terrorismo como delito común para todos los efectos legales, privándole del privilegio extraditorio y de la posibilidad de indulto.

${ }^{11}$ Íbid. párrafo 38 de consideraciones de fondo.

${ }^{12}$ El ilícito constitucional consumado y acreditado con las pruebas anteriores, no puede desaparecer por el becho de que en distintas declaraciones pueda el señor Almeyda haberse manifestado un defensor de la democracia y de los derechos inherentes a ella, pues tales actitudes están abiertamente reñidas no solo con su carácter de marxista-leninista t...) sino que ellas corresponden a la esencia de la moral marxista que, como es sabido, "está enteramente subordinada a los intereses de la lucha de clases del proletariado". Íbid, párrafo 87 de consideraciones de fondo.

${ }^{13}$ Votos de mayoría: Ministros Sres. José María Eyzaguirre, Enrique Ortúzar E., Marcos Aburto O. y Eduardo Urzúa M.. Votos disidentes: Ministros Sres. Eugenio Valenzuela S., Julio Philippi I., y Luis Maldonado B..

${ }^{14}$ El terrorismo, en cualquiera de sus formas, es por esencia contrario a los derechos bumanos.

Una ley de quórum calificado determinará las conductas terroristas y su penalidad. Los responsables de estos delitos quedarán inhabilitados por el plazo de quince años para ejercer funciones o cargos públicos, sean o no de elección popular, o de rector o director de establecimientos de educación o para ejercer en ellos funciones de enseñanza; para explotar un medio de comunicación social o ser director o administrador del mismo, o para desempeñar en el funciones relacionadas con la emisión o difusión de opiniones o informaciones; ni podrán ser dirigentes de organizaciones políticas o relacionadas con la educación o de carácter vecinal, profesional, empresarial, sindical, estudiantil o gremial en general, durante dicho plazo. Lo anterior se entiende sin perjuicio de otras inhabilidades o de las que por mayor tiempo establezca la ley.

Los delitos a que se refiere el inciso anterior serán considerados siempre comunes y no políticos para todos los efectos legales y no procederá respecto de ellos el indulto, salvo para conmutar la pena de muerte por la de presidio perpetuo. 
Luego en el Capítulo II, acerca de nacionalidad y ciudadanía, mediante los arts. 16 y 17 se establecen la suspensión y privación de derechos políticos. En el art $16 \mathrm{~N}^{\circ} 2$ se suspende el derecho a sufragio para el acusado de delitos de terrorismo, y el art $17 \mathrm{~N}^{\circ} 3$ priva de la ciudadanía por condena por delitos de terrorismo.

\subsection{El carácter político y atentatorio contra derechos humanos del terrorismo}

Del conjunto de los artículos 9, 16 y 17 puede deducirse que el pronunciamiento que la Constitución hace respecto del terrorismo implica el reconocimiento de su carácter político, pero, como veremos, en una determinada dirección. Desde el punto de vista normativo, el artículo $9^{\circ}$ es un mandato de punición ${ }^{15}$ cuya justificación política se encontraría en la declaración de ser este "esencialmente contrario a los derechos humanos", lo que no deja de ser - parafraseando a Ruiz Tagle- mera retórica constitucional, pensando en el terrorismo de Estado. Complementando esta afirmación, y yendo al origen del art. 9, la contradicción con los derechos humanos no parece apuntar al sentido clásico de las mismas (violaciones masivas y sistemáticas de derechos por parte del Estado a ciudadanos), sino más bien al atentado contra el sistema establecido, pues de otra forma no se explica el tipo de sanciones accesorias que la norma establece, todas estas se refieren a la posibilidad de participar en la vida política, económica y social, así como las suspensiones de derechos políticos. Pero no se trata de cualquier sistema establecido, sino el sistema establecido por la dictadura militar. Entonces, más que retórica constitucional, hay una falacia argumentativa, pues quien designa al terrorismo como contrario a los derechos humanos es el poder constituyente de un Estado que tuvo a su cargo una estrategia masiva y sistemática de violación a los mismos, que es el auténtico sentido a las violaciones a derechos humanos que podría encontrarse en el terrorismo ${ }^{16}$.

A mayor abundamiento, el mandato del artículo 9 no protege al ciudadano frente al Estado, sino al revés, protege al Estado del que se transforma en terrorista. Es "un mandato de la Constitución al Estado para ejercer esa potestad" compeliéndolo a punir ${ }^{17}$. No es un simple mandato de criminalización del terrorismo, sino de tipificación. Esto porque en sintonía con la norma antecesora (art. 8), el art. 9 tuvo por fin confrontar a la disidencia política, espíritu que desgraciadamente todavía parece resonar en algunas posturas parlamentarias ${ }^{18}$ e interpretaciones

${ }^{15}$ BCN. Historia de la Ley $N^{\circ} 20.050 \ldots$, de 26 de agosto 2005, p. 160.

${ }^{16}$ Así se viene afirmando desde la década del 70, en una ardua polémica. Por todos, David, E. "Le terrorisme en droit international", en Actes du colloque Réflexions sur la définition et la répression du terrorisme, Editorial de l'Université Libre de Bruxelles, Bruselas, 1974, pp. 103-173, p. 110.

${ }^{17}$ Opinión de Bascuñán Rodríguez, en Historia de la Ley $N^{\circ} 20.050 \ldots$. p. 161.

18 Por ejemplo, el proyecto de ley que "Sanciona las conductas que indica, en relación con los hechos de gobiernos que hayan transgredido la Carta Fundamental y las leyes”. Boletín N N $^{0} 0492-07$ de 6-012015, que pretende sancionar con penas de cárcel a quienes enaltezcan la figura de Salvador Allende y su gobierno. Explícitamente en su fundamentación alude solo al gobierno de Salvador Allende como transgresor de garantías constitucionales, como la libertad de asociación y reunión. Paradójicamente nada dice acerca del gobierno militar. 
judiciales ${ }^{19}$. Esa podría ser una explicación acerca del porqué la ley de conductas terroristas en nuestro país se ha aplicado en la última década a la criminalidad de indígenas y antisistémicos ${ }^{20}$. En la región de La Araucanía y en el marco del conflicto territorial, la aplicación de la ley de conductas terroristas y su invocación por parte del órgano persecutor se fundamenta en que la finalidad de quienes cometen ciertos delitos (p.ej. incendios de fundos) es la de causar temor en una parte de la población (empresas forestales, particulares no indígenas o descendientes de colonos), en aplicación de las normas pertinentes del Código Penal en relación con el art. 1 de la Ley 18.314. No obstante, esta no se aplica a otras conductas que también persiguen causar temor a la población como los casos cada vez más reiterados de narcotraficantes y pandillas que incendian la casa de sus rivales o incluso los queman vivos ${ }^{21}$. En este punto cabe precisar que si bien no existe un concepto unívoco de terrorismo, doctrinariamente es posible identificar a lo menos tres elementos en él: teleológico (finalidad política: socavar o destruir el

19 Así por ejemplo, en el caso de un acusado por el delito terrorista de colocación de artefactos explosivos, que fue condenado por delito común de la Ley 17.798, sobre control de armas, al momento de pronunciarse respecto de las pruebas el Tribunal Oral en lo Penal señaló: Aun cuando puede estimarse que la reunión de todo este material, alguno de ellos de carácter abiertamente insurreccional, habría demostrado que el acusado adhería a alguna ideología de carácter anarquista, el Tribunal tuvo presente que, como se adelantó, que los diversos documentos encontrados en el computador que ocupaba en su lugar de trabajo el acusado, no le pueden ser atribuidos de manera inequívoca y en consecuencia tampoco la creación de los documentos individualizados por los peritos $\left(7^{\circ}\right.$ Tribunal Oral en lo Penal de Santiago. Sentencia de 12-07-2013, RUC 1101243950-6, RIT 45-2013, considerando décimo, el subrayado es nuestro). Interpretado a contrario sensu este párrafo, si se hubiese probado que los documentos eran suyos me pregunto si eso significaría que por compartir la ideología anarquista era terrorista. A mayor abundamiento, luego en la Corte de Apelaciones resolviendo la solicitud de pena sustitutiva, el argumento para denegarla fue: (...) si bien es posible considerar que los móviles que llevan al imputado a obrar de esta manera, obedece a sus convicciones intimas, que por muy equivocadas que estén, obra en consecuencia de ellas, su conducta posterior demuestra que no hace ningún intento por revisarlas a lo menos para insertar su conducta en el medio social donde pertenece. Lo anterior queda demostrado con su actitud de no comparecer ante la autoridad luego de que le fuera revocada su libertad provisional, conducta que no solo llegó a ese punto, sino que además emitió mensajes a la sociedad desafiando abiertamente el sistema judicial desde que da entrevistas a medios de comunicación, explicando el motivo de su rebeldía y persistencia en su conducta antijurídica. Corte de Apelaciones de Santiago. Sentencia de 29-10-2013, rol 2789-2013, considerando séptimo.

${ }^{20}$ Bajo el concepto de "antisistémico" se agrupan varios colectivos que se oponen al sistema establecido, pero en Chile la criminalización se ha dirigido al movimiento anarquista y su entorno. Paradigmático es el Caso Bombas, $3^{\circ}$ Tribunal Oral en lo Penal de Santiago. Sentencia de 13-07-2012, RUC: 0700277303-6, RIT: 138-2011; Corte de Apelaciones de Santiago. Sentencia de 27-09-2011, rol No 1459-2011 (acumuladas 1498-2011 y 1539-2011), y Corte de Apelaciones de Santiago. Sentencia de 10-10-2012, rol No 5654-2012.

${ }^{21}$ Ver Villegas, M. "Estado de excepción y antiterrorismo en Chile. Criminalización de la protesta social con especial referencia a los indígenas", en Revista de Derecho Penal y Criminología, año III, núm. 6, 2013 , pp. 3-25, p.14. Un hecho dramático y que puede ser observado vivamente por el lector, se da en un reportaje de uno de los programas más populares de la televisión chilena "En su propia trampa" (Canal 13). Dos periodistas al interior de una casa de una familia en una populosa comuna de Santiago, graban en vivo un ataque por parte de una pandilla a la casa sabiendo que estaba la familia dentro incluidos niños. Atacan primero con armas de fuego y luego mediante incendio que alcanza también a edificios contiguos, afectando a veinte familias. La familia atacada refiere que uno de sus integrantes fue asesinado y quemado en semanas anteriores, y que sus rivales, en son de burla, se refieren a él como "el ceniza". Disponible en: http://www.13. cl/programas/en-su-propia-trampa-t5/capitulos/en-su-propia-trampa-capitulo-13 (consulta: 20-01-2016). 
sistema democrático), estructural (organización terrorista que lleva a cabo una estrategia de dominación por el terror) e instrumental (medios idóneos para provocar terror) ${ }^{22}$. Ninguno de ellos se recoge en la actual Ley 18.314, la que construye los tipos penales a partir de un elemento subjetivo consistente en la finalidad interna del sujeto al momento de cometer la conducta, de causar temor a la población o un sector de ella (arts. 1 y 2 Ley 18.314).

En el caso de los grupos antisistémicos, y tratándose de la colocación de artefactos explosivos o incendiarios, si un sujeto relacionado con grupos anarquistas pone un artefacto explosivo en la puerta de un banco a altas horas de la madrugada, se lo acusa de cometer delito de terrorismo, sin embargo no se registran acusaciones por delito de terrorismo a sujetos que hacen estallar cajeros automáticos con un artefacto explosivo similar, para llevarse el dinero. En este último caso, y como hasta la Ley 20.813 de febrero de 2015 no había tipo penal específico que sancionara la colocación de artefacto explosivo en la ley penal común, la conducta era calificada como delito de daños o se consideraba al explosivo como medio para cometer el robo (concurso ideal medial). Sin embargo, en el caso del anarquista, la formalización por delitos de terrorismo era casi segura ${ }^{23}$.

Los tribunales intentaban paliar esta irritante diferencia de trato restringiendo al máximo la calificación terrorista, y por regla general, en la sentencia se imputaba la conducta a delitos comunes, pero toda la investigación se había llevado a cabo bajo el procedimiento restrictivo de garantías de la ley de conductas terroristas ${ }^{24}$, la que incluye, como veremos, importantes restricciones a la libertad personal establecidas constitucionalmente.

La formulación autoritaria del constituyente, manifestada en el tenor literal del art. 9, impide también y de plano la resocialización al imponer sanciones accesorias de inhabilitación desproporcionadas ${ }^{25}$ que impiden la participación democrática y confluyen con las que legalmente correspondiere. Esto porque si al terrorista se lo castiga por atentar contra el sistema establecido, o contra la democracia, y la sanción consiste en privarlo de participar en la misma, no se entiende en qué medida puede integrarse o volver a participar del sistema. En mi opinión, estamos ante una sanción accesoria que

${ }^{22}$ Sigo en esto a Terradillos, J. "El Estado de derecho y el fenómeno del terrorismo", en Demetrio, E. y Serrano PiedeCasas, J.R.(Dirs.), Terrorismo y Estado de derecho, Editorial Iustel, Madrid, 2010, pp. 271-292. Profusamente acerca del tema, mostrando las diversas formas de conceptualización en el actual escenario latinoamericano y mundial, véase Villegas, Myrna. "Contribuciones para un concepto de terrorismo en el derecho penal chileno”, en Revista Política Criminal, Vol. 11, No 21, julio 2016, pp. 140-172.

${ }^{23}$ Este problema ha sido resuelto con la Ley 20.813 de 6 de febrero de 2015, que crea un tipo penal específico de colocación de artefactos explosivos. Ver arts. 14 D) y 17 B) de la Ley 17.798.

${ }^{24}$ Ver nota $N^{\circ} 19$, también $4^{\circ}$ Tribunal Oral en lo Penal de Santiago. Sentencia de 15-08-2012, RIT O-150-2012 (vs. L. Pitronello), Tribunal Oral en lo Penal de Puente Alto. Sentencia de 15-06-2014, RUC 1300145684-3 (vs. V. Montoya).

${ }^{25}$ Ruiz Tagle sostiene que la norma del art. 9 es injustificadamente excepcional tanto por contener un mandato específico y restrictivo al legislador penal como por sancionar en forma desproporcionada, e incluso, múltiple, un mismo hecho (se refiere a las sanciones accesorias más la pérdida de la ciudadanía). Ruiz Tagle, P. 2002, op. cit., p.14. 
tiene un fin retributivo e inocuizador y que atenta contra la igualdad ante la ley consagrada en el art. 24 de la Convención Americana de Derechos Humanos (CADH), pues no hay ninguna sanción similar para otros casos.

En cuanto a la suspensión del derecho a sufragio para el acusado por delitos de terrorismo, puede sostenerse una interpretación similar. Si se le suspenden derechos a aquel cuya culpabilidad todavía no ha sido probada en juicio, parece evidente la finalidad de neutralización de su conducta manifestada en una determinada opción política, pues el constituyente en la balanza que debe usarse previo a la suspensión de derecho político, hace primar la calificación terrorista por sobre la presunción de inocencia consagrada en el art. 14.2 del Pacto Internacional de Derechos Civiles y Políticos y en el art. 8.2 de la Convención Americana de Derechos Humanos ${ }^{26}$.

El Tribunal Constitucional ha reforzado esta norma aun cuando presenta contradicciones con normas establecidas en tratados internacionales de derechos humanos ratificados por Chile y vigentes, cuyo rango superior al de otros viene dado por el art. 5 inciso 2 de la Constitución. Pronunciándose respecto del control de constitucionalidad del entonces proyecto de ley acerca de inscripción automática, Servicio Electoral y sistema de votaciones, declaró que siendo los delitos de terrorismo de aquellos que merecen pena aflictiva, podrían perfectamente caber en la hipótesis de estos últimos para fundamentar la suspensión del derecho a sufragio, pero al contener el artículo 9 un notable repudio al terrorismo como si fuera una base de la institucionalidad, y en el inciso 2 autorizar sanciones específicas que operan sin perjuicio de otras inhabilidades que establezca la ley, había que concluir que la existencia de una regla constitucional refuerza la excepcionalidad y demuestra que el supuesto terrorista tiene una doble autorización de suspensión de derechos politicos ${ }^{27}$.

La pérdida de la ciudadanía es otra muestra de la finalidad inocuizadora del constituyente respecto del terrorista, pues lo aparta de la vida política y social, existiendo otra excepción al principio de igualdad (art. $24 \mathrm{CADH}$ ), pues establece restricciones respecto de su rehabilitación que no existen en otras formas de criminalidad. La rehabilitación de la calidad de ciudadano solo puede solicitarse al Senado, una vez cumplida la condena. En el caso más cercano, la condena a pena aflictiva, basta con la extinción de la responsabilidad penal que supone el cumplimiento de la condena.

En suma, es posible afirmar, de un lado, que con las penas accesorias, la suspensión del derecho a sufragio, y la pérdida de la ciudadanía, se cierran para el terrorista los canales de participación política,vetando cualquier posibilidad de diálogo y discusión política o ideológica con el mismo. De otro lado, da cuenta de al menos una tensión entre la suspensión

${ }^{26}$ En esta interpretación Villegas, M. Terrorismo: un problema de Estado. Tratamiento jurídico del terrorismo en la legislación comparada. Especial referencia a los delitos de terrorismo en las legislaciones de Chile y España. Tesis Doctoral, Universidad de Salamanca, 2002, Disponible en: http://repositorio.uchile.cl/tesis/uchile/2001/ villegas_m/html/index-frames.html (consulta: 20-01-2016).

Sin el análisis político criminal que aquí se realiza, sino simplemente indicando que afecta la presunción de inocencia, ver Aguirre, F. y Bustos, R. 2014, op. cit., p. 184.

27 Tribunal Constitucional. Sentencia de 19-01-2012, rol No 2152-11, parte resolutiva, prevención No 16 del Ministro Sr. García Pino en relación con la suspensión del derecho a sufragio, p. 156. 
del derecho a sufragio del todavía no condenado y la presunción de inocencia ${ }^{28}$, así como entre la restricción a la rehabilitación de la calidad de ciudadano y el principio de igualdad. Es admisible tener presente que si bien la Comisión Interamericana ha reconocido a los Estados cierto margen de apreciación en la interpretación del art. 23 de la CADH, que consagra el derecho a voto, la posibilidad de ser elegido en cargos de elección popular, así como el igual acceso a las funciones públicas, este margen de apreciación es estrecho, pues las razones para su restricción son taxativas. El art. 23.2 hace referencia a "la edad, nacionalidad, residencia, idioma, instrucción, capacidad civil o mental, o condena, por juez competente, en proceso penal", lo que podría de alguna manera justificar las restricciones para el condenado, pero nunca para el no condenado ${ }^{29}$.

Sin perjuicio de lo expuesto, de lege data, es posible realizar una interpretación integrativa y utilitaria de los arts. 9, 16 y 17 de la Constitución, y el art. 1 de la Ley 18.314, que permita considerar, a efectos de su aplicación práctica, que no cualquier acto es terrorista sino solo aquel que tiene una finalidad política en el sentido de socavar la democracia y para ello utiliza como estrategia el atentado contra derechos humanos fundamentales ${ }^{30}$, lo que a su vez supone la presencia de una organización capaz de llevar adelante dicha estrategia. Con relación a esto último, no ha sido pacífica la discusión acerca de si actores no estatales tengan la capacidad de diseñar y llevar a cabo una estrategia de violación a derechos humanos fundamentales, y tiene sentido ante la asimilación que se ha hecho en algunos países del terrorismo interno con un crimen contra la humanidad ${ }^{31}$.

Esta es, en palabras de Landa, una cuestión abierta ${ }^{32}$, pero que no debiera conducir a una banalización del concepto de crímenes contra la humanidad en el sentido de asimilar el denominado "terrorismo doméstico" o de baja intensidad con dichos crímenes. Por el contrario, esta asimilación debiera provocar un constreñimiento de las tipificaciones internas, pues si terrorismo es asimilable a una violación sistemática de derechos humanos fundamentales, huelga concluir -junto con los criterios que ha dado la Corte Penal Internacional ${ }^{33}$ - que

${ }^{28}$ Ampliamente, Barrientos, Ignacio. "Suspensión del derecho de sufragio por acusación penal. Vulneración constitucional de la presunción de inocencia”, en Revista de Estudios Constitucionales, N 2, 2011, pp. 249-328.

29 En esta interpretación, Íbid., p. 293.

${ }^{30}$ Villegas, M. "Procesos de Reforma en Chile: Aproximaciones desde el campo del Derecho Penal Político”, en Amaral, B. (coord.), Justiça Criminal e Democracia II, Editorial Marcial Pons, São Paulo, 2015, pp.231-269, p.264. También en la jurisprudencia: Tribunal de Juicio Oral en lo Penal de Temuco. Sentencia de 28-02-2014, RUC: $1300014341-8$, RIT: 220-2014, considerando vigésimo sexto.

31 Así ha sucedido por ejemplo, en la Ley 4/2008, de 19 de junio, de Reconocimiento y Reparación a las víctimas del terrorismo (Boletín Oficial del País Vasco No 124, 1, julio 2008).

32 Landa Gorostiza, J., "La sombra de los crímenes contra la humanidad en la política antiterrorista española: Reflexiones críticas”, en Revista electrónica de ciencia penal y criminología, núm. 12, 2010, disponible en: http://criminet.ugr.es/recpc (consulta: 20-01-2016), pp. 1-30, pp. 12 y ss.

33 Decisión de la Sala de Cuestiones Preliminares II (Pre-trial Chamber II) de la Corte Penal Internacional de 31 de marzo de 2010 que autoriza el inicio de una investigación concerniente a la situación en la República de Kenia. ICC-01/09 de 31 marzo 2010, pp.45 y ss. Disponible en: https://www.icc-cpi.int/ en_menus/icc/situations $\% 20$ and $\% 20$ cases/situations/situation $\% 20 \mathrm{icc} \% 200109 /$ court $\% 20$ records/chambers/ pretrial\%20chamber\%20ii/Pages/19.aspx (consulta: 29-01-2016). Ver comentarios a la misma en Landa, 2010, op. cit., pp. 12 y ss. 
la misma solo podría ser llevada a cabo bajo el alero de una organización criminal, bien estructurada, con posibilidades reales de incidir en un cambio político y de imponer una determinada voluntad política atentando contra el derecho a la libre autodeterminación de un pueblo, y no por pequeños grupos de autodefensa, o por individuos solitarios. La afirmación reinante de que el "terrorismo doméstico es tan grave como un crimen contra la humanidad" 34 no solo es conceptualmente incorrecta, sino pareciera tener un fin instrumental, castigar como terroristas a todos aquellos a los cuales no se les puede probar pertenencia a una organización ${ }^{35}$.

\subsection{El terrorismo como delito común y la negación del indulto particular}

Respecto de la consideración constitucional del terrorismo como delito común y no político, ella tiene por finalidad impedir que a su respecto proceda el privilegio extraditorio, esta es una norma común en la mayoría de las legislaciones en el mundo, cuya procedencia es, como se ha indicado antes, la cláusula belga o del atentado ${ }^{36}$, pero tampoco es sometido al tratamiento de los delitos comunes, pues se establece que respecto de los delitos de terrorismo no procederá el indulto particular salvo para conmutar la pena de muerte por la de presidio perpetuo. Más allá de la decimonónica e improcedente referencia a la pena de muerte, que está abolida en nuestro país hace ya casi dos décadas, merece la pena una referencia al indulto particular.

La negación del indulto particular para casos de terrorismo encuentra su fundamento en la necesidad que tiene el Estado de defenderse de la violencia política, asimilada muchas veces a terrorismo, lo que permite un uso relativamente discrecional en función de las circunstancias. Baste como ejemplo la disposición transitoria séptima de la Constitución ${ }^{37}$ que establece una excepción al art. 9 permitiendo el indulto particular para supuestos de terrorismo cometidos con anterioridad al 11 de marzo de 1990, fecha que marca el término de la dictadura y el inicio de la transición democrática. Esto refleja el carácter de arma política que tienen las amnistías y los indultos para los poderes ejecutivos, quienes las han usado como herramientas en función de la coyuntura política y a criterios de conveniencia o inconveniencia ${ }^{38}$.

${ }^{34}$ Críticamente Landa, 2010, op. cit., p. 3.

${ }^{35}$ Críticamente acerca de los denominados "lobos solitarios", Villegas, M. 2016, op. cit., p. 163.

${ }^{36}$ Es pertinente indicar que ella no existía en forma expresa al dictarse la Constitución de 1980. Actualmente se consagra en el Tratado de Extradición entre Chile y España de 14 de abril de 1992, cuyo art. 5.1 indica: "No se concederá la extradición por delitos considerados políticos o conexos con delitos de esta naturaleza... A los efectos de este tratado no se considerarán en ningún caso como delitos políticos: a) El atentado contra la vida, la integridad física o la libertad de un jefe de Estado o de Gobierno, o de un miembro de su familia".

${ }^{37}$ Disposición transitoria séptima: "El indulto particular será siempre procedente respecto de los delitos a que se refiere el artículo $9^{\circ}$ cometidos antes del 11 de marzo de 1990 . Una copia del decreto respectivo se remitirá, en carácter de reservado, al Senado". Introducida por Ley de reforma constitucional N ${ }^{\circ} 19.055$ de 1 de abril de 1991.

${ }^{38}$ Muñoz Conde, F. y García Arán, M., Derecho Penal. Parte General, $3^{a}$. Ed., Editorial Tirant lo Blanch, Valencia, 1998, p. 451. Así por ejemplo, en Chile el DL 2.191 de 1978, autoamnistía que aprobó el régimen militar con el propósito de "perdonar" los crímenes cometidos por personeros del régimen entre 1973 y 1978. 
Este carácter se confirma cuando posteriormente entre el 2004 y 2005 se otorga el indulto para conmutar penas a los privados de libertad en la cárcel de Alta Seguridad, algunos de ellos condenados por ley de conductas terroristas, y que habían delinquido con posterioridad a 1990. Para ello, y en el caso específico de condenados por delitos de terrorismo, la Ley 20.042 de 2005 estableció un mecanismo que si bien no era un indulto, cumplió su misma función. Estableció la posibilidad de otorgar libertad condicional para los condenados a presidio perpetuo por Ley 18.314, una vez cumplidos 10 años de pena y siempre que hubieren delinquido entre 1989 y 1998, pero solicitándoles expresamente que suscribieran en forma previa una declaración inequívoca de renuncia a la violencia ${ }^{39}$.

El artículo 9, así como los arts. 16 y 17, han permanecido casi intactos a pesar de las sucesivas reformas constitucionales. En la última gran reforma (Ley 20.050 de 2408-2005), quiso ampliarse su aplicación al narcotráfico, al secuestro y la desaparición forzada de personas, así como a toda otra forma de crimen organizado ${ }^{40}$, idea que no prosperó.

Conectando estas ideas con el caso inicialmente descrito acerca de apología del terrorismo y la declaración de don Clodomiro Almeyda como "persona inconstitucional", no está de más destacar que la ley de conductas terroristas ha sido aplicada preferentemente a la disidencia política. Nunca han sido condenados por esta ley agentes estatales o con nexos con el Estado, oficiales o no oficiales, que cometieron delitos entre 1984 (año de promulgación de la ley de conductas terroristas) y 1990. Solo en el conocido caso de los tres profesores degollados por agentes policiales (Caso Degollados) la sentencia de primera instancia condenó a los policías como autores del delito de homicidio terrorista ${ }^{41}$. Sin embargo, esta calificación fue desestimada por las Cortes de Apelaciones y Suprema, condenándolos por delito común ${ }^{42}$. En otros casos similares, no hubo siquiera procesamientos por esta ley, pudiendo perfectamente calificar como terrorista la Operación Albania o matanza de Corpus Christie en $1987^{43}$, en donde un grupo de

${ }^{39}$ Artículo único: A los condenados a presidio perpetuo por delitos contemplados en la Ley $N^{\circ} 18.314$, que fija la penalidad por conductas terroristas $y$, además condenados por delitos sancionados en otros cuerpos legales, se les podrá conceder el beneficio de la libertad condicional, una vez cumplidos 10 años de pena, siempre que los hechos punibles hayan ocurrido entre el 1 de enero de 1989 y el 1 de enero de 1998, y los condenados suscriban en forma previa una declaración que contenga una renuncia inequivoca al uso de la violencia.

${ }^{40}$ Historia de la Ley $N^{\circ} 20.050 \ldots$, pp. 33, 158.

${ }^{41} 6^{\circ}$ Juzgado del Crimen de Santiago. Sentencia de 31-03-1994, rol No 118-284, Ministro en visita extraordinaria Sr. Milton Juica. En ella se condena a la mayoría de los procesados por los delitos de secuestro calificado y homicidio calificado terroristas, asociación ilícita terrorista y otros.

${ }^{42}$ Corte de Apelaciones de Santiago. Sentencia de 30-09-1994, rol No 16.169-94, confirma el fallo condenatorio pero con declaraciones, por considerar que no es aplicable la Ley 18.314. Calificó las conductas como delitos comunes, lo que trajo consigo una rebaja automática de las penas y dejar sin efecto las penas accesorias del art. 9 de la Constitución. Confirmada por Corte Suprema. Sentencia de 27-10-1995, rol No 31.030-94.

43 Gobierno de Chile. Informe Comisión Nacional de Verdad y Reconciliación. Volumen I, Tomo II, Corporación Nacional de Reparación y Reconciliación, Andros Impresores, Reedición 1996, pp. 1002 y ss. Disponible en: http://www.ddhh.gov.cl/ddhh_rettig.html (consulta: 20-01-2016). Ver también http://www.archivochile.com/ Derechos_humanos/html/dd_hh_albania.html (consulta: 20-01-2016). 
agentes de la DINA disparó a un grupo del FPMR que se encontraba reunido en una casa, el homicidio del estudiante Ronald Wood (1989) en el marco de una protesta nacional $^{44}$, y el caso de los dos jóvenes quemados por una patrulla militar que le costó la vida al fotógrafo Rojas Denegri ${ }^{45}$. De esta forma, la balanza punitiva del terrorismo en los tribunales se ha inclinado a un solo lado, a la criminalidad no estatal, excluyendo al auténtico terrorismo: el de Estado.

\section{EL TERRORISMO EN LAS GARANTÍAS CONSTITUCIONALES}

\section{La ampliación constitucional de los plazos de detención}

El artículo $19 \mathrm{~N}^{\circ} 7$ de la Constitución Política consagra el derecho a la libertad personal y la seguridad individual, pero establece dos importantes excepciones para casos de terrorismo. La primera dice relación con la ampliación a diez días del plazo de detención (art. $19 \mathrm{~N}^{\circ} 7$ letra c) en lugar de las 72 horas que ordinariamente corresponde a una detención ampliada (art. 132 Código Procesal Penal). La resolución del juez debe, en todo caso, ser fundada. Esta norma está replicada en el art. 11 de la Ley 18.314, y perfeccionada mediante la primera ley adecuatoria de la reforma procesal penal (Ley 19.806 de 31-05-2002).

El mandato constitucional nuevamente obliga al sistema penal a posicionarse en pro de la eficacia de la investigación policial y la efectividad de la investigación, en desmedro de una garantía constitucional. Lo más grave es que esta norma, en la medida que regula una situación que se produce al inicio de una investigación es potencialmente aplicable a cualquier ciudadano que pueda verse involucrado con personas o situaciones que sean calificados como terroristas tanto por la policía como por el órgano persecutor.

Ahora bien, si el fundamento material de la prórroga de plazo es, entre otras, la necesidad en el avance de la investigación, no se ve en modo alguno cómo se puede avanzar en la investigación cuando el detenido es privado de su derecho a comparecer ante el juez de garantía para que revise la legalidad de la detención, considerando que la declaración de ilegalidad de la misma impide, conforme al CPP (art. 132), solicitar dicha ampliación. Por lo demás, y como lo establece el CPP que rige en lo no previsto

44 Íbid., p.1108.

45 Ídem. Ver también: http://www.casosvicaria.cl/temporada-dos/el-fotografo-que-vino-a-morir-a-chile/. (consulta: 07-01-2016).También: Federación de Colegios Profesionales Universitarios de Chile, "El caso de Rodrigo Rojas y Carmen Gloria Quintana: El límite del horror”, Disponible en: http://www.bcn.cl/archivohales/ colecciones/v/participacion-politica-y-membresias/el-caso-de-rodrigo-rojas-denegri-y-carmen-gloria-quintanael-limite-del-horror.?t=10221.1/27836\&v=dc\&r=Documento (consulta: 20-01-2016). El caso, a cargo del Ministro en Visita extraordinaria, Sr. Mario Carroza, fue reabierto en julio de 2015 a raíz de las declaraciones de un ex conscripto que permitió el procesamiento de varios exoficiales y exsuboficiales de Carabineros. Así como la entrega de documentación confidencial por parte de EE.UU. que revelan que hubo presiones por parte del gobierno militar. Ver: http://www.efe.com/efe/america/politica/documentos-de-ee-uu-revelan-quepinochet-encubrio-el-caso-quemados/20000035-2678286 (consulta: 20-01-2016). 
por la Ley 18.314, el juez debe acceder a la ampliación cuando haya antecedentes que justifiquen esa medida, como por ejemplo, que el fiscal reúna las pruebas necesarias para preparar su presentación de formalización de la investigación. No, en cambio, cuando se detiene a una persona en el marco de una investigación ya iniciada, cuyas pruebas arrojan preliminarmente la identificación de uno o más autores o intervinientes en el delito, y en razón de ello son detenidos ${ }^{46}$.

Todo parece apuntar entonces a que la ampliación de la detención pueda transformarse en un puente directo hacia la práctica de procedimientos fuera de la ley para obtener una confesión del detenido, práctica que fue frecuente en tiempos de dictadura militar ${ }^{47}$, pero que tampoco parece haber sido del todo abandonada en estos tiempos ${ }^{48}$ pese a la prohibición expresa de la misma en el CPP (art. 195).Y así se siguen registrando casos de tortura o apremios ilegítimos en el contexto de detenciones ${ }^{49}$.

De todas formas, en la ley de conductas terroristas se establece un resguardo para la integridad física del detenido: la obligación del juez de garantía en caso de ordenar la ampliación, de disponer que este ingrese en un recinto penitenciario y sea examinado por un médico designado por él. Este nombramiento no puede recaer en ningún funcionario que pertenezca al organismo policial que efectuó la detención o en cuyo poder se encontrare el detenido. Sin embargo, es factible preguntarse si podría recaer en un médico perteneciente a otro organismo policial, toda vez que el texto legal no se ocupa de indicar que corresponde a los facultativos del Servicio Médico Legal, institución que el legislador reconoce como autorizada para el asesoramiento médico legal que

46 Como sucedió en el caso del bombazo en el metro Escuela Militar, en donde, a pesar de que el fiscal contaba con los antecedentes necesarios para formalizar, toda vez que había logrado identificar a los responsables, solicitó igualmente una ampliación del plazo de detención a cinco días. Entrevista a Defensor Regional Metropolitano de 14 de octubre de 2014, realizada en el contexto del proyecto de investigación Fondecyt. Ver también, http:/www.emol.com/noticias/nacional/2014/09/18/680917/se-amplio-ontrol-dedetencion-de-acusados-por-atentados-explosivos-en-el-metro.html (consulta: 20-1-2016).

${ }^{47}$ Durante el régimen militar la Ley 18.314 establecía la facultad para practicar detenciones a las Fuerzas de Orden y Seguridad Públicas y a la Central Nacional de Informaciones (CNI), organismo de inteligencia del Ejército (art. 12 antigua Ley 18.314). Posteriormente esta norma no tuvo razón de ser al ser disuelta la CNI cuando asumió el poder el gobierno de la transición democrática.

${ }^{48}$ Por ejemplo, en 2009 y en el marco de la investigación por delito de terrorismo se presentó una querella para que se esclarecieran apremios ilegítimos en contra de un mapuche para obtener una confesión, acreditándose las lesiones practicadas por la policía. El Ministerio Público decidió no perseverar en la investigación, decisión que fue refrendada por el Juzgado de Garantía y luego por la Corte de Apelaciones de Temuco argumentando esta última que la facultad de no perseverar es privativa del Ministerio Público, no pudiendo oponerse a esa decisión el Tribunal. Corte de Apelaciones de Temuco. Sentencia de 07-07-10, RIT 7576-2009, RUC: 0910022461-2, rol N 496-10.

${ }^{49}$ Ver Tribunal de Juicio Oral en lo Penal de Puente Alto. Sentencia de 23-12-10, RUC 0900396663-9. UDP. Informe Anual sobre Derechos Humanos 2015. Centro de Derechos Humanos Universidad Diego Portales Santiago, 2015, pp.140 y ss. En el año 2012 se registraron 1.775 denuncias por violencias innecesarias en contra de carabineros (casi cinco diarias), todas entregadas al conocimiento de la justicia militar. En el mismo período las tasas de sentencias condenatorias no superan el 1,78\% de las denuncias presentadas. INDH. Situación Anual de los Derechos Humanos en Chile. Informe Anual 2013. Instituto Nacional de Derechos Humanos, Santiago, 2013, pp.81 y ss. 
las investigaciones judiciales determinen. Esto porque tampoco en el Código Procesal Penal, que rige en subsidio de lo no regulado en la Ley 18.314, se establece esta labor respecto del SML, más bien las referencias al mismo se hacen respecto de los exámenes y procedimientos para esclarecer ciertos hechos punibles, pero no para resguardar la integridad física de un detenido ${ }^{50}$

Con todo, hay una contradicción entre la norma constitucional que permite la ampliación del plazo de detención y los artículos 7 y 8 de la $\mathrm{CADH}$, pues las normas de debido proceso respecto de la privación de libertad deben tener carácter general y no tener excepciones para ciertos casos o personas, considerando además que este tipo de normas no admiten restricción ni suspensión como ocurre con otras normas de derechos humanos $^{51}$. Si bien el art. 7.2 de la CADH establece la posibilidad de que la privación de libertad se regule constitucionalmente ${ }^{52}$, esta regulación de acuerdo con la CADH se refiere a las causas y condiciones de la privación de libertad, pero no a la posibilidad de ampliar plazos de detención.

En la práctica, la ampliación del plazo de detención para casos de terrorismo fue bastante profusa en tiempos de dictadura y en los primeros años de la transición democrática, pero en la actualidad, y según la información que hemos recabado concerniente a causas por terrorismo a partir de 2004 parece no haberse hecho uso de dicha norma. Cuando se ha ampliado el plazo de detención, en general, ha sido dentro del rango que es pertinente a toda clase de delitos.

\section{Limitaciones constitucionales a la libertad y reforzamiento de la prisión preventiva}

El art. $19 \mathrm{~N}^{\circ} 7$ letra e) al consagrar la garantía de libertad para el imputado, hace referencia expresa a los delitos de terrorismo en su inciso 2, en los siguientes términos:

La apelación de la resolución que se pronuncie sobre la libertad del imputado por los delitos a que se refiere el artículo $9^{\circ}$, será conocida por el tribunal superior que corresponda, integrado exclusivamente por miembros titulares. La resolución que la apruebe u otorgue requerirá ser acordada por unanimidad. Mientras dure la libertad, el imputado quedará siempre sometido a las medidas de vigilancia de la autoridad que la ley contemple.

La norma contiene dos excepciones a la regla general, la primera dice relación con la integración de la sala de la corte de apelaciones que debe conocer de la resolución

${ }^{50}$ DFL N 196 de 4 de abril de 1960, que fija texto de la Ley Orgánica del Servicio Médico Legal. Arts. 2 y 3 .

${ }^{51}$ Medina, C. "Derechos Humanos y aplicación de la Ley 18.314, que determina las conductas terroristas y fija su penalidad”, en Informes en Derecho. Doctrina Procesal Penal 2012, Defensoría Penal Pública, núm.12, octubre 2013, pp. 7-60, p.39.

52 Artículo 7. Derecho a la Libertad Personal. 2. Nadie puede ser privado de su libertad física, salvo por las causas y en las condiciones fijadas con anticipación por las Constituciones Políticas de los Estados Partes o por las leyes dictadas conforme a ellas. 
que se pronuncia acerca de la libertad, sea que la apruebe o deniegue. Solo puede estar compuesta por ministros titulares, quedando excluidos los abogados integrantes, a diferencia de lo que ocurre para el resto de los casos (art. 62 del COT). La segunda, es que el acuerdo de dicha sala debe adoptarse por unanimidad y no por mayoría, como es la regla general (art.72 del COT). Esta disposición constitucional ha generado bastantes problemas, existiendo interpretaciones dispares sobre la misma, y a diferencia de la norma que la precede que regula la ampliación del plazo de detención, esta disposición sí ha tenido aplicación en todos los casos.

Ella nació a la vida jurídica con la ley de reforma constitucional $\mathrm{N}^{\circ} 19.055$ de 1 de abril de 1994, que tenía por objeto posibilitar la aplicación del indulto particular a condenados por delitos de terrorismo cometidos antes de $1990^{53}$. Posteriormente fue objeto de reforma por la Ley 20.050 de 26 de agosto de 2005, que no cambió su esencia, solo eliminó de su texto original lo relativo al trámite de "consulta" ante la Corte de Apelaciones por resultar improcedente después de la entrada en vigencia de la reforma procesal penal.

A la época de su incorporación, esto es, al inicio de la transición democrática, el recién asumido gobierno se encontró ante la necesidad de propiciar las iniciativas legales necesarias para lograr la reconciliación nacional ${ }^{54}$, razón por la que, y para abordar los casos de terrorismo, impulsó un proyecto de ley que culminó con dos importantes reformas: de un lado, permitió la aplicación del indulto particular respecto de delitos de terrorismo cometidos antes de 11 de marzo de 1990 (disposición transitoria séptima de la Constitución). De otro lado, permitió el otorgamiento de la entonces llamada "libertad provisional" para presos preventivos por delitos de terrorismo, posibilidad que legalmente se encontraba vedada toda vez que el art. 17 de la Ley 18.314 en su versión original de 1984 disponía escuetamente que respecto de los delitos contemplados en el artículo $1^{\circ}$ no procederá la libertad provisional de los procesados.

Dicho artículo fue derogado recién once años más tarde, mediante la Ley 19.806 de 31-5-2002, conocida como la primera ley adecuatoria de la reforma procesal penal. Por tanto, entre 1991 y 2002 el párrafo del art. 19 N 7 letra e) de la Constitución que se comenta se erigía casi como una norma protectora del derecho a ser juzgado en libertad para el acusado por delitos de terrorismo, porque establecía simplemente una "restricción" para la obtención de la libertad y no una negación de ella como señalaba la

${ }^{53}$ La disposición original introducida por la Ley 19.055 señalaba: La resolución que otorgue la libertad provisional a los procesados por los delitos a que se refiere el artículo $9^{\circ}$, deberá siempre elevarse en consulta. Esta y la apelación de la resolución que se pronuncie sobre la excarcelación serán conocidas por el tribunal superior que corresponda, integrado exclusivamente por miembros titulares. La resolución que apruebe u otorgue la libertad requerirá ser acordada por unanimidad. Mientras dure la libertad, el reo quedará siempre sometido a las medidas de vigilancia de la autoridad que la ley contemple. Ver: BCN. Historia de la Ley $N^{\circ}$ 19.055: Reforma constitucional sobre indulto, amnistía y libertad provisional. Santiago, 1996, p. 105.

${ }^{54}$ Lo señala expresamente en el mensaje del proyecto de reforma constitucional sobre indulto, amnistía y libertad provisional (Boletín 229.-07 de 14 diciembre de 1990, ver ibíd., p. 1). 
Ley 18.314. Y en tal sentido, hasta podía pensarse en la inconstitucionalidad del antiguo art. 17 en el tiempo que coexistió con el reformado art. $19 \mathrm{~N}^{0} 7$ letra e) ${ }^{55}$.

En la actualidad, la disposición no parece tener correlato normativo coherente, pues las causales que ameritan una prisión preventiva están establecidas para toda clase de delitos en el art. 140 del CPP, y son concretamente: el peligro para el éxito de la investigación, el peligro de fuga, y el peligro para la sociedad, por lo que si es igual para todos los casos no se entiende por qué debería ser distinta la integración del tribunal y el quórum en casos de terrorismo. Ello sin descontar que tan solo las dos primeras, esto es, peligro para la investigación y peligro de fuga, están consideradas en el sistema interamericano de derechos humanos para el otorgamiento de la prisión preventiva ${ }^{56}$.

En la mayoría de los casos por terrorismo el fundamento para denegar la libertad es la gravedad del delito, y este a su vez es uno de los criterios que por mandato legal debe seguir el juez para establecer la existencia de un peligro para la seguridad de la sociedad. Considerando que los delitos de terrorismo son siempre graves, y sus penas son también muy altas, las posibilidades de obtención del beneficio de ser procesado en libertad se difumina, máxime si debe cumplirse con la restricción constitucional. Así, como efecto de la aplicación combinada del art. 140 del CPP y del art. $19 \mathrm{~N}^{\circ} 7$ letra e) de la Constitución, la prisión preventiva se transforma en una verdadera pena anticipada, pues muchos de los imputados arriesgan esperar la sentencia estando privados de libertad $^{57}$, lo que no se condice con el mandato establecido en el mismo Código procesal penal, que ordena tratar al imputado preso preventivo en todo momento como inocente (art. 150 inciso 3). Esto es particularmente grave si consideramos que en todos los casos que se ha invocado la ley de conductas terroristas ha existido prisión preventiva, y en todos ellos se solicitó libertad en varias oportunidades ${ }^{58}$. En algunos casos la resolución del juez de garantía sustituyó la prisión preventiva por la medida cautelar de arresto domiciliario, pero luego era revocada por unanimidad por la Corte de Apelaciones ${ }^{59}$. En otras oportunidades la libertad fue denegada por el juez de garantía y luego confirmada por unanimidad por la Corte de Apelaciones ${ }^{60}$.

De acuerdo con los antecedentes recabados en nuestra investigación, esta norma también fue aplicada a un menor de edad, cuando ellos podían ser juzgados por delitos de terrorismo ${ }^{61}$. Mediante la Ley 20.467 de 8-10-2010 se modificó el artículo $1^{\circ}$ de la Ley 18.314 sobre conductas terroristas, señalando expresamente que los menores de

${ }^{55}$ En esta interpretación Villegas, M. 2002, op. cit., Capítulo III, 2.b.2. - La prisión provisional y la excarcelación.

56 Medina, C. 2013, op. cit., p. 37.

${ }^{57}$ Ibid, p.38.

$587^{\circ}$ Juzgado de Garantía de Santiago, RIT 45-2013, vs. Hans Niemayer, Juzgado de Garantía de Temuco, RIT 220-2014, vs. Celestino Córdoba, $7^{\circ}$ Juzgado de Garantía de Santiago, RIT 150-2012, vs. Luciano Pitronello.

${ }^{59}$ Esto sucedió en tres oportunidades en la causa del $7^{\circ}$ Juzgado Garantía de Santiago, RIT 45-2013, vs. Hans Niemayer.

${ }^{60}$ Juzgado de Garantía de Temuco, RIT 220-2014, vs. Celestino Córdoba, $7^{\circ}$ Juzgado de Garantía de Santiago, RIT 150-2012, vs. Luciano Pitronello.

${ }^{61}$ Villegas, M. 2015, op. cit., pp. 231-269, pp. 265-266. 
edad no podían ser condenados por ella. La disposición modificatoria fue interpretada a contrario sensu por el órgano persecutor y por los jueces, en el sentido de que no podían ser condenados pero sí sometidos a proceso e investigados bajo el procedimiento de dicha ley, razón por la que, y tratándose de revisar la medida de internación provisoria respecto de los menores, los tribunales entendieron que era aplicable lo dispuesto por el art.19 N 7 letra e) de la CPR. Así, la Corte de Apelaciones de Temuco por resolución de 27-10-2010 confirmó la medida cautelar de internación provisoria decretada por el juez de garantía para un menor mapuche en Caso Tur Bus, a pesar de que dos de los ministros estuvieron de acuerdo en revocarla y solo uno por confirmarla ${ }^{62}$. Meses más tarde, y encontrándose en funcionamiento la sala de verano de la misma Corte, acordó revocar la medida y someterlo a arresto domiciliario, arraigo nacional y firma quincenal ${ }^{63}$.

En junio de 2011, mediante la Ley 20.519, se reformó nuevamente la ley de conductas terroristas, impidiendo que esta se aplique a menores de edad.

El reforzamiento de la prisión preventiva mediante esta disposición constitucional ha sido también interpretado de otra forma por la Corte de Apelaciones de San Miguel, quien afirma que la norma hace referencia al otorgamiento de la libertad respecto del privado de ella por delitos de terrorismo, pero no es aplicable la limitación cuando se trata de sustituir la medida cautelar de prisión preventiva por la de arresto domiciliario total, por cuanto esta no supone una puesta en libertad del sujeto, sino una restricción -aunque menos severa- de su libertad. Y así, la resolución de sustituir la cautelar por otra de similar naturaleza no queda sujeta a lo dispuesto por el art. $19 \mathrm{~N}^{\circ} 7$ de la Constitución, pudiendo ella ser acordada por simple mayoría y no por unanimidad de los integrantes de la sala ${ }^{64}$.

Lo preocupante de toda esta normativa es que desde 2005 en adelante parece no haber condenas por delitos de terrorismo. El Ministerio Público registra aproximadamente diecinueve $\operatorname{casos}^{65}$, de ellos, dos aún están en investigación ${ }^{66}$. Según la información y jurisprudencia que hemos recabado, con posterioridad a las condenas de mapuches en los casos de los lonkos Norín y Pichún, Ancalaf, y algunos del incendio al fundo Poluco Pidenco, los imputados por ley de conductas terroristas o bien han sido absueltos por falta de participación, o condenados por delitos comunes, desestimándose solo al final del proceso judicial, esto es, en la sentencia, la calificación terrorista ${ }^{67}$. En algunos casos los imputados que terminaron absueltos habían cumplido un año y 4 meses en prisión

${ }^{62}$ Corte de Apelaciones de Temuco. Resolución de 27-10-10, rol No 0900969218-2.-50-842-2010.

${ }^{63}$ Corte de Apelaciones de Temuco. Resolución de 11-02-11, RUC 900969218-2-50-145-2011.

${ }^{64}$ Corte de Apelaciones de San Miguel. Resolución de 8-02-13, N 170-2013-REF.

${ }^{65}$ Las cifras del Departamento de Informática y Estadística (DIE) de la Defensoría Penal Pública dan cuenta de 428 imputados por delitos de terrorismo entre 2001 y 2015. Las causas suelen tener varios imputados.

${ }^{66}$ Casos de bombas en estación de metro Los Dominicos y Escuela Militar, hechos acaecidos el 13-7 y 23-9 de 2014, respectivamente, y bomba en el barrio Yungay de Santiago causando un muerto, ocurrido el 25-9-2014.

${ }^{67}$ Villegas, M., 2015, op. cit., pp.231-269, p.261-263. Los registros del DIE de la Defensoría Penal Pública muestran 82 condenados entre 2001 y 2015 en causas por terrorismo, sin que pueda saberse si lo fueron por delito de terrorismo o por delito común, y si una o más de ellas son posteriores a 2005. 
preventiva, uno de ellos dos años ${ }^{68}$. Se exceptúa de esta regla general un caso en donde sí hubo condena por delitos de terrorismo ${ }^{69}$.

De ahí entonces que la normativa constitucional no solo esté siendo un escollo en el desarrollo de los principios que deben impregnar el sistema penal democrático, sino más bien impulsando la aplicación de institutos que derechamente los vulneran.

\section{RAZONES PARA EXCLUiR AL TERRORISMO DE LA CONSTITUCIÓN}

El examen anterior da cuenta de lo que estimo una derivación del "abuso de la forma constitucional"70, y debería ser un sólido argumento como para excluir al terrorismo de toda referencia constitucional en una futura Carta Fundamental. Pero pudiera ser que, a la luz de la expansión, surgiera el argumento contrario, esto es, la necesidad de contemplar un mandato constitucional para reforzar el repudio de los sistemas democráticos al terrorismo, así como para instalar una barrera constitucional a las eventuales limitaciones de garantías que pudiere establecer el legislador ${ }^{71}$.

${ }^{68}$ Así sucedió en Caso Tur Bus, cuyos imputados estuvieron privados de libertad entre 2009 y 2011, a pesar de haber solicitado insistentemente la libertad. Ver por ejemplo las siguientes resoluciones, todas estas confirmaban la medida cautelar de prisión preventiva, al principio por unanimidad, y luego por mayoría: Corte de Apelaciones de Temuco. Resolución de 27-10-09, rol No 921-2009, que confirma cautelar para J. Queipul,Victor Queipul, Camilo Tori, Felipe Huenchullan y Jose Millanao, Resoluciones de 23-04-10, audio RUC 900969218-2-50-294-2010; Resolución de 14-07-10, audio RUC 9000969218-2-50-5332010; Resolución de 15-07-10, audio RUC 900969218-2-50-536-2010; Resolución de 26-08-10, audio RUC 900969218-2-50-666-2010, Resolución de 15-09-10 y 28-10-10, 30-11-10 confirman con un voto en contra atendido a que es demasiado el tiempo trascurrido en que llevaban privados los imputados de libertad. Rol No 0900969218-2-50-729-2010; Rol Nº900969218-2-50-846-2010; Rol No 09009692182-960-2010. Recién en febrero de 2011 la Corte de Apelaciones de Temuco decide revocar la medida cautelar de internación provisoria para los imputados Luis Marileo, Ernesto Cayupan, Felipe Huenchullan, Víctor Queipul, Camilo Toris, José Queipul, y cambiarlas por medidas cautelares personales, Corte de Apelaciones de Temuco. Resolución de 11-02-2011, audio RUC 900969218-2-50-145-2011. Más tarde la misma Corte ordena mantener la prisión preventiva para José Queipul en Corte de Apelaciones de Temuco. Resolución de 20-04-2011, audio RUC 900969218-2-50-370-2011.

${ }^{69}$ Se trata de una persona mapuche que participaba como testigo con reserva de identidad en diversos procesos. En uno de ellos a petición de la defensa hubo de ser formalizado como coimputado (caso peaje Quino). Sin embargo no lo fue ante el mismo tribunal que el resto, sino en otro. Habiéndose acogido al beneficio de atenuación de pena del art. 4 de la Ley 18.314 (arrepentimiento eficaz) fue condenado en un procedimiento abreviado por los delitos de homicidio frustrado terrorista y asociación ilícita terrorista, otorgándosele el beneficio de libertad vigilada. Juzgado de Garantía de Victoria. Sentencia de 22-10-2010, RIT 1134-2009/ RUC 0900969218-2 vs. Raúl Castro Antipán. Lo paradójico es que por estos hechos fue el único condenado por delito de terrorismo, pues al momento de la acusación en el TOP de Angol, los otros presuntos intervinientes fueron acusados por delitos comunes, entre ellos asociación ilícita común, pero absueltos por falta de participación, mediante Sentencia del TOP de Angol de 29-08-2012, R.U.C. 0900969218-2/ R.I.T. 58-2012 (Caso Peaje Quino) vs. Víctor Queipul, José Millanao, et al. S.TOP de Temuco de 29-08-2013, R.U.C.: 0900697670-8 R.I.T.: 099/2013 (Caso Tur bus).

${ }^{70}$ Sobre este concepto, Atria, F. La Constitución tramposa, Editorial LOM, 2013, p. 41.

${ }^{71}$ En esta interpretación Carrasco, M. 2010, op. cit., p.18. 
Por razones de extensión no entraremos a fondo en la discusión acerca de cuál es el rol que debiera cumplir la Constitución con relación al sistema penal, y si debemos orientarnos por una postura sistemática o dogmática-penal o una postura sustancial o constitucional, que pueda llevar a la consideración de un derecho penal constitucional ${ }^{72}$, simplemente dejar planteado que hay razones de orden político y de orden normativo que aconsejan evitar en las constituciones los mandatos de punición, y que en el caso del terrorismo son más políticas que normativas.

En cuanto a las razones de orden político, si bien es cierto las constituciones autoritarias pudieran parecer más cercanas a la realidad en determinados contextos ${ }^{73}$, medios de protección represivos como los que se estilan a propósito del terrorismo no robustecen la Constitución, su efecto es simplemente eliminar del espectro político a determinadas fuerzas, empujándolas hacia la ilegalidad ${ }^{74}$. Ello queda de manifiesto en el caso de la Constitución chilena vigente desde que impide al terrorista cualquier participación en la vida política con posterioridad a su condena. Al transgredir uno de los principios básicos de la democracia, la posibilidad de participar en la vida nacional, sea directamente o por medio de sus representantes, así como la posibilidad de acceder en igualdad de condiciones a la función pública, derechos consagrados en tratados internacionales ratificados por Chile ${ }^{75}$, queda en entredicho la legitimidad del sistema democrático.

Esto porque la legitimidad de dicho sistema político encuentra asidero en un consenso democrático cuya validez depende de la concurrencia de todos los sectores en la formación de la voluntad política, así como en el respeto a la separación de poderes. Y cuando la Constitución contiene un mandato de punición restrictivo de garantías pareciera un nexo para el aumento de las facultades del Ejecutivo en desmedro de los otros poderes $^{76}$, lo que pudiera conducirnos al autoritarismo. En este último se produce un desajuste entre las instancias jurídicas y políticas, aun cuando los mecanismos formales de la democracia representativa se mantengan intactos, así como el consenso que los legitima. Pero ya no se trata de canales de participación reales o materiales,

${ }^{72}$ Durán, M. "Constitución y legitimación de la pena. Apuntes teleológicos sobre el rol de la Constitución en el sistema penal”, en Política criminal, vol. 6, núm. 11, junio 2011, Art. 5, pp. 142-162, pp. 145 y ss. Disponible en: http://www.politicacriminal.cl/Vol_06/n_11/Vol6N11A5.pdf (consulta: 20-01-2016).

73 Ver Elkins, Z.; Ginsburg, T. y Melton, J. “The Content of Authoritarian Constitutions”, en Ginsburg, T. y Simpser, A., Constitutions in Authoritarian Regimes, Cambridge University Press, 2013, pp. 141-164. Disponible en: https:/www.sas.upenn.edu/dcc/sites/www.sas.upenn.edu.dcc/files/uploads/ DCCGinsburgauthconsts_penn.pdf (consulta: 22 de enero de 2015).

${ }^{74}$ Schneider, H. "Problemas de la constitución de emergencia y de la legislación de emergencia a la luz de la Ley Fundamental”, en Demasi, C. et al., Estado de Derecho y Estado de excepción: Alemania y Uruguay: las décadas violentas, Ediciones Trilce y Goethe Institut, Montevideo, 1999, p. 102.

75 Declaración Universal de Derechos Humanos (art. 21. 1 y 2), en el PIDCP (art. 25) y en la CADH (art. 23).

76 Reconociendo la acentuación de poderes del ejecutivo a causa de las limitaciones a derechos fundamentales, Carrasco, M. 2010, op. cit., p. 38. 
sino formales, con lo que el postulado democrático comienza a tambalearse, pudiendo transitarse hacia una crisis de legitimación ${ }^{77}$.

Coincido con quienes afirman que la protección de los derechos fundamentales vía constitucional se traduce en establecer mandatos de abstención para el Estado, en forma tal que ciertos derechos básicos de las personas no puedan verse afectados ${ }^{78}$. Ello debe estar en sintonía con los tratados internacionales de derechos humanos, resguardando que al menos aquellos derechos que no pueden verse suspendidos por ninguna circunstancia (p.ej. art. $8 \mathrm{CADH}$ ) sean respetados. Y eso no tiene por qué ser diferente para los delitos de terrorismo. No obstante la forma mediante la que se establecen estos resguardos es una tarea que compete al legislador, con una orientación constitucional del uso del derecho penal como ultima ratio.

En el caso de la constitución chilena vigente sucede exactamente al revés, pues el mandato de punición respecto del terrorismo y su refuerzo vía establecimiento de sanciones accesorias especiales, supone una afectación reforzada para el ciudadano cuyas garantías constitucionales, por disposición de la propia Constitución, pueden verse menoscabadas por las limitaciones generales en estados de normalidad constitucional (ej. caso de limitaciones en el marco de una investigación judicial), como en casos de anormalidad constitucional (estados de excepción) ${ }^{79}$.

De ahí que las normas respecto del terrorismo en la Constitución de 1980 suponen paradójicamente una doble anomalía constitucional ${ }^{80}$, pues de un lado compelen al legislador a tipificar conductas en un determinado sentido por medio de una ley de quórum calificado ${ }^{81}$, afectando con ello una política legislativa democrática, y por otro impone medidas que afectan la libertad de las personas, así como sus derechos ciudadanos.

Además, y en el plano normativo, considerando que las constituciones son normas jurídicas y no meros programas, debe tenerse presente su condición de "coto vedado" y de las normas en ella incluidas, su rigidez y la posibilidad de aplicación directa ${ }^{82}$. Esto supone entonces, en el caso chileno, que si el legislador quisiera reformar la ley de conductas terroristas para eliminar una norma que repite lo señalado por la Constitución tendría que entrar a un examen de constitucionalidad. A este respecto, el pronunciamiento acerca de la constitucionalidad de las normas antiterroristas en la jurisprudencia del Tribunal Constitucional chileno es muy escaso. Más bien no existen sentencias que se refieran a ellas, con excepción de la suspensión de derechos políticos para acusados por delitos de

77 Villegas, M. 2002, op. cit., Capítulo III, b.1.Consecuencias a nivel social y político: La desvirtuación de los postulados social y democrático del Estado de Derecho.

${ }^{78}$ Intervención de Antonio Bascuñán, en BCN. Historia de la Ley No 20.055 ..., p. 162.

${ }^{79}$ En este sentido Ruiz-Tagle, P. 2002, op. cit., p. 4.

${ }^{80}$ Intervención de Antonio Bascuñán, en BCN. Historia de la Ley No $20.055 \ldots$. p. 162.

${ }^{81}$ Acerca de la función de las leyes de quórum calificado como "trampas constitucionales", Atria, F. op. cit., pp. 46-47.

${ }^{82}$ Ver Carrasco, M. 2010, op. cit., p. 56. En el mismo sentido, Informe de la Comisión de Expertos del Ministerio del Interior y la Seguridad Pública del Gobierno de Chile sobre la regulación jurídica de las conductas terroristas, de 13.10. 2014, p. 7. 
terrorismo, cuya constitucionalidad fue afirmada por el Tribunal Constitucional cuando se manifestó pertinente al proyecto de ley de reforma electoral para inscripción automática $^{83}$, que finalmente se plasmó en la Ley 20.568 de 31 enero $2012^{84}$.

Lo anterior no significa que las normas de la ley de conductas terroristas no hayan sido impugnadas. Han existido varios requerimientos de inaplicabilidad por inconstitucionalidad, la mayoría de estas han sido declaradas inadmisibles ${ }^{85}$, y uno que habiendo sido declarado admisible, aunque sin orden de no innovar, fue desistido por el recurrente porque después de la vista de la causa, la norma decisoria litis de la ley de conductas terroristas cuya inaplicabilidad había sido planteada, ya no lo era en el juicio, pues la sentencia fue dictada durante la tramitación del requerimiento habiendo sido el imputado condenado por delitos comunes y no terroristas ${ }^{86}$.

Es decir, el panorama a nivel de tribunal constitucional tampoco es alentador, lo que es preocupante a la luz de las restricciones que la Constitución establece a garantías fundamentales.

Finalmente, de contemplarse el terrorismo en la Constitución, tendríamos, a decir de Atria ${ }^{87}$, normas "formalmente (=jurídicamente) constitucionales, pero substantivamente (=políticamente) legales", es decir, normas que no son fundamentales, sino que suponen la existencia previa de un fundamento ${ }^{88}$, y ese fundamento es lo discutible, pues lleva inserto un componente político que es variable según quien ejerza el poder.

\section{CONSIDERACIONES FINALES}

No hay argumentos de peso que obliguen al Estado de Chile a pronunciarse constitucionalmente acerca del terrorismo. Su regulación a nivel constitucional no es una tendencia consolidada en la legislación comparada, y más bien conlleva el peligro de afectación a derechos humanos fundamentales, supuesto que las referencias constitucionales en estos casos son siempre para autorizar restricciones de garantías, careciendo esto de sentido si consideramos que estas restricciones las puede establecer el legislador.

${ }^{83}$ Tribunal Constitucional. Sentencia de 19-01-12, rol No 2152-2011.

${ }^{84}$ Ley 20.568. Artículo 17.- Dentro de los cinco primeros días de cada mes, los Juzgados de Garantía deberán comunicar al Servicio Electoral las personas que, en el mes anterior, hayan sido acusadas por delito que merezca pena aflictiva o por delito que la ley califique como conducta terrorista.

En la misma oportunidad, los Juzgados de Garantía y los Tribunales Orales en lo Penal, según corresponda, deberán comunicar al Servicio Electoral las personas que bubieren sido condenadas por delitos que merezcan pena aflictiva, aunque no se haya impuesto dicha pena, o por delitos que la ley califique como conducta terrorista, o que fueren absueltas o sobreseídas por tales delitos.

${ }^{85}$ Tribunal Constitucional. Sentencias roles Nos. 2815-2015, 2825-2015, 1826-2010.

86 Tribunal Constitucional. Requerimiento de inaplicabilidad 2564-2013, resolución de 1 de abril de 2014 .

${ }^{87}$ Atria, F. op. cit., p. 19.

${ }^{88}$ Ídem. 
Más bien autorizarlas constitucionalmente puede significar un abuso de la forma constitucional para fines netamente políticos.

La regulación actual del terrorismo en la Constitución chilena muestra serias contradicciones con los principios de presunción de inocencia e igualdad protegidos por la Convención Americana de Derechos Humanos, supuesto que la doble autorización para suspensión de derechos políticos no tiene parangón en nuestro derecho, ni siquiera en otras formas graves de criminalidad, en las que tampoco existe un reforzamiento de la prisión preventiva establecido constitucionalmente como ocurre en el caso del terrorismo. El hecho de que la Constitución declare que el terrorismo es esencialmente contrario a los derechos humanos no basta, pues por consiguiente la mayoría de los delitos atentan contra derechos humanos, y tampoco es este el único elemento que lo define jurídicamente.

Por ello es que una nueva Constitución debería guardar silencio respecto del terrorismo y devolver su regulación íntegra al legislador, el que a su vez debe hacerlo de manera tal que no deslice en los jueces una responsabilidad que en último término es política, lo que implica, de entrada, abandonar la idea tentadora de crear tipos penales abiertos que terminen convirtiéndose en cajones de sastre en donde encuadre todo tipo de conducta social o políticamente reprochable.

\section{BIBLIOGRAFÍA}

Aguirre, F. y Bustos, R. "Terrorismo y Constitución de 1980, con especial referencia a la aplicación de la ley antiterrorista en el marco del conflicto del Estado con el Pueblo mapuche", en Anuario de Derecho Público, Universidad Diego Portales, 2014, pp.173-201.

ATria, F. La Constitución tramposa, Editorial LOM, 2013.

BARrientos, Ignacio. "Suspensión del derecho de sufragio por acusación penal. Vulneración constitucional de la presunción de inocencia”, en Revista de Estudios Constitucionales, $\mathrm{N}^{\circ} 2$, 2011, pp. 249-328.

BCN. Historia de la Ley $N^{\circ}$ 19.055: Reforma constitucional sobre indulto, amnistía y libertad provisional. Santiago, 1996.

Carrasco, M., "Medidas antiterroristas y constitución tras el 11 de septiembre de 2001", en Pérez Royo, J. (dir.) y Carrasco, M. (coord.), Terrorismo, democracia y seguridad, en perspectiva constitucional, Editorial Marcial Pons, Madrid, 2010.

DAvid, E. "Le terrorisme en droit international", en Actes du colloque Réflexions sur la définition et la répression du terrorisme, Editorial de l'Université Libre de Bruxelles, Bruselas, 1974, pp. 103-173.

Durán, M. "Constitución y legitimación de la pena. Apuntes teleológicos sobre el rol de la Constitución en el sistema penal”, en Política criminal, vol. 6, núm. 11, junio 2011, pp. 142-162, disponible en: http://www.politicacriminal.cl/Vol_06/n_11/Vol6N11A5. pdf (consulta: 20-01-2016).

Elkins, Z.; Ginsburg, T. y Melton, J. “The Content of Authoritarian Constitutions”, en Ginsburg, T. y Simpser, A., Constitutions in Authoritarian Regimes, Cambridge University Press, 2013, pp.141-164. Disponible en: https://www.sas.upenn.edu/dcc/sites/www.sas.upenn.edu.dcc/ files/uploads/DCCGinsburgauthconsts_penn.pdf (consulta: 22-01-2016). 
Gobierno de Chile. Informe Comisión Nacional de Verdad y Reconciliación. Volumen I, Tomo II, Corporación Nacional de Reparación y Reconciliación, Andros Impresores, Reedición 1996, disponible en: http://www.ddhh.gov.cl/ddhh_rettig.html (consulta: 20-01-2016).

INDH. Situación Anual de los Derechos Humanos en Chile. Informe Anual 2013. Instituto Nacional de Derechos Humanos, Santiago, 2013.

LANDA Gorostiza, J., "La sombra de los crímenes contra la humanidad en la política antiterrorista española: Reflexiones críticas”, en Revista electrónica de ciencia penal y criminología, núm. 12, 2010, disponible en: http://criminet.ugr.es/recpc (consulta: 20-01-2016), pp.1-30.

Medina, C. "Derechos Humanos y aplicación de la Ley 18.314, que determina las conductas terroristas y fija su penalidad", en Informes en Derecho. Doctrina Procesal Penal 2012, Defensoría Penal Pública, núm.12, octubre 2013, pp. 7-60.

Muñoz Conde, F. y García Arán, M., Derecho Penal. Parte General, 3a. Ed., Editorial Tirant lo Blanch, Valencia, 1998.

Ruiz-TAGLe, P. "Constitucionalismo y terrorismo", en SELA (Seminario en Latinoamérica de Teoría Constitucional y Política), Paper $\mathrm{N}^{\circ}$ 12, 2002, disponible en: http://digitalcommons.law.yale. edu/yls_sela/12 (consulta: 20-01-2016).

Schneider, H. "Problemas de la constitución de emergencia y de la legislación de emergencia a la luz de la Ley Fundamental", en Demasi, C. et al., Estado de Derecho y Estado de excepción: Alemania y Uruguay: las décadas violentas, Ediciones Trilce y Ghoete Institut, Montevideo, 1999.

Terradillos, J. "El Estado de derecho y el fenómeno del terrorismo”, en Demetrio, E. y Serrano PiedeCasas, J.R.(Dirs.), Terrorismo y Estado de derecho, Editorial Iustel, Madrid, 2010, pp. 271-292.

UDP. Informe Anual sobre Derechos Humanos 2015. Centro de Derechos Humanos Universidad Diego Portales Santiago, 2015.

Villegas, M. Terrorismo: un problema de Estado. Tratamiento jurídico del terrorismo en la legislación comparada. Especial referencia a los delitos de terrorismo en las legislaciones de Chile y España. Tesis Doctoral, Universidad de Salamanca, 2002, Disponible en: http://repositorio.uchile.cl/tesis/ uchile/2001/villegas_m/html/index-frames.html (consulta: 20-01-2016).

"Estado de excepción y antiterrorismo en Chile. Criminalización de la protesta social con especial referencia a los indígenas", en Revista de Derecho Penal y Criminología, año III, núm. 6, 2013, pp. 3-25.

"Procesos de Reforma en Chile: Aproximaciones desde el campo del Derecho Penal político", en Amaral, B. (coord.), Justiça Criminal e Democracia II, Editorial Marcial Pons, Sao Paulo, 2015, pp.231-269.

"Contribuciones para un concepto de terrorismo en el derecho penal chileno", en Revista Política Criminal, Vol. 11, No 21, Julio 2016, pp. 140-172.

Zilli, M.; Monteconrado, F. y Moura, M.T., "Terrorismo e o direitto brasileiro”, en Ambos, K.; Malarino, E. y Steiner, C. (eds.), Terrorismo y derecho penal, Konrad Adenauer Stiftung, Edpal, Bogotá, 2015, pp. 521-553. 
